\title{
Halls, Gods, and Giants: The Enigma of Gullveig in Óðinn's Hall
}

Tommy Kuusela

Stockholm University

\section{Introduction}

The purpose of this article is to discuss and interpret the enigmatic figure of Gullveig. I will also present a new analysis of the first war in the world according to how it is described in Old Norse mythic traditions, or more specifically, how it is referred to in Veluspá. This examination fits into the general approach of my doctoral dissertation, where I try to look at interactions between gods and giants from the perspective of a hall environment, with special attention to descriptions in the eddic poems. ${ }^{\mathrm{I}}$ The first hall encounter, depending on how one looks at the sources, is described as taking place in a primordial instant of sacred time, and occurs in Óðinn's hall, where the gods spears and burns a female figure by the name of Gullveig. She is usually interpreted as Freyja and the act is generally considered to initiate a battle between two groups of gods - the Æsir and the Vanir. I do not agree with this interpretation, and will in the following argue that Gullveig should be understood as a giantess, and that the cruelty inflicted upon her leads to warfare between the gods (an alliance of Æsir and Vanir) and the giants (those who oppose the gods' world order). The source that speaks most clearly about this early cosmic age and provides the best description is Veluspá, a poem that is generally considered to have been composed around 900I000 AD. ${ }^{2}$

How to cite this book chapter:

Kuusela, T. 20I9. Halls, Gods, and Giants: The Enigma of Gullveig in Óðinn's Hall. In: Wikström af Edholm, K., Jackson Rova, P., Nordberg, A., Sundqvist, O. \& Zachrisson, T. (eds.) Myth, Materiality, and Lived Religion: In Merovingian and Viking Scandinavia. Pp. 25-57. Stockholm: Stockholm University Press. DOI: https://doi.org/Io.I6993/bay.c. License: CC-BY. 


\section{The Problem of Gullveig in Voluspá}

Gullveig is only mentioned in Voluspá. The poem narrates how Óðinn seeks out a volva who recounts the major events in the Creation, and the eventual destruction, of the world. In the beginning, after the world has been created, the volva, who herself might be a giantess, ${ }^{3}$ speaks of a "golden age" for the gods, which is broken by the coming of three mighty giantesses. The episode is hard to comprehend, and many commentators seem to identify the three female figures with the Norns (even though they actually appear later, in stanza 20). Nothing more is said of these women. After this, the poem speaks of the creation of dwarves, humans, and how fate is measured by the three Norns. After the fates have been introduced, the poem again returns to the topic of the gods and describes how the volva remembers the first war in the world, and how the gods immolated a figure known as Gullveig. As John McKinnell ${ }^{4}$ has pointed out, the following two stanzas: "constitute one of the most familiar problems in the study of Eddic poetry".

2 I Pat man hon fólcvíg fyrst í heimi, er Gullveigo geirom studdo oc í holl Hárs hána brendo; prysuar brendo, prysuar borna, opt, ósialdan, pó hon enn lifir. ${ }^{5}$

She remembers the first war in the world, when they stuck Gullveig with spears and in the High-One's hall they burned her;

three times they burned her, three times she was reborn, over and over, yet she lives still. ${ }^{6}$

22 Heiði hana héto, hvars til húsa kom, volo velspá, vitti hon ganda;

seið hon, hvars hon kunni, seið hon hug leikinn, a var hon angan illrar brúdar. ${ }^{7}$

Bright One [Heiðr] they called her, wherever she came to houses, the seer with pleasing prophecies, she practised spirit-magic, she knew seid, seid she performed as she liked [practised magic in a trance], she was always a wicked woman's favourite. ${ }^{8}$ 
Both stanzas are as fascinating as they are challenging, but it is primarily stanza $2 \mathrm{I}$ that is the motivation for this article. In that stanza, the volva says that she remembers fólcvíg fyrst $i$ heimi and speaks of how "they" (most likely the gods) stabbed a figure called Gullveig with spears and burned her in the High One's hall. Not just on one occasion, but three times - and every time she is reborn. The subsequent stanza speaks of yet another figure, called Heiðr, who practise seiðr, and say that she was a wicked woman's favourite.

The name Gullveig is mentioned in Voluspá on one single occasion, in a mythical context that is difficult to interpret. The stanza that mentions her is puzzling and opens up for many interpretations. What is the meaning of this, and who, or what, is this cryptic figure called Gullveig? Why do the gods torture her, and how does this affect them? Was this incident considered significant, and how can it be explained? In the following, I will try to argue that Gullveig can be explained, and that she fits into a pattern of conflict and interaction between gods and giants in Old Norse mythology. Before I present my own point of view, it is necessary to give a brief summary of earlier interpretations.

\section{How Was this Episode Explained in Earlier Studies?}

Naturally, there have been many different explanations for the Gullveig episode, from the I 800 s until the present day. There is not enough space to mention all of them and I will only refer to those that I believe have been most significant. This will be done chronologically and as briefly as possible, before I present my own reading of the text.

An early - and probably the most influential - analysis of the Gullveig episode was presented by Karl Müllenhof, ${ }^{9}$ who believed that Gullveig was a personification of gold. For him, she represented the destructive powers of gold, as well as its seductive and ensnaring influences. He argued that she was the same person as Heiðr and that she could be identified with the volva who speaks in the poem. ${ }^{\text {Io }}$ Sophus Bugge, on the other hand, thought that Gullveig was one of the Æsir and that she was killed by the Vanir in Óðinn's Hall. For him, the episode explained how the war broke out. He did not believe that Heiðr was the same being 
as Gullveig and assumed that she (Heiðr) was a giantess and the narrator in the poem. ${ }^{\text {II }}$

Elard Hugo Meyer argued for a Christian context and believed that the influence of Christian literature was evident in Vqluspá. He compared Gullveig with Ambrose's comment on Eve in Paradise, who was beguiled into sin by the Devil's poisonous arrows. This, in turn, was associated with descriptions in the Bible of the Whore of Babylon, both in the Book of Revelation and in Jeremiah, where she is called the golden goblet (calix aureus) and it is said that she must burn. He also thought that the war in Voluspá referred to God's war with the fallen and rebellious angels. ${ }^{\mathrm{I2}}$

Another line of thought was to try to trace Gullveig back to classical sources. Wolfgang Krause ${ }^{\mathrm{I} 3}$ compared Gullveig with Pandora, while H. W. Stubbs ${ }^{14}$ tried to find a link between Norse and Greek myths, where Gullveig was seen as a combined version of Eris and Aphrodite. Georges Dumézil presented yet another explanation. He compared the episode with a Roman legend that speaks of how the city of Rome was founded. In the Roman narrative, two different tribes, the Sabines (compared with the Vanir), and another group that follows Romulus (compared with the Æsir) wage war for the region that would later become Rome. The Sabines have almost conquered the city by bribing a woman, Tarpeia, from their opponent's side (with gold or love, according to two different accounts). Dumézil thought that this legend could be used to explain the fact that Gullveig was sent to the Æsir by the Vanir, where she corrupts them with a strong craving for gold, a desire that manifests itself among the Æsir goddesses. ${ }^{15}$

Robert Höckert ${ }^{16}$ claimed that the war between the gods was at the heart of Voluspá, and that it was its major topic. He believed that the poem described a religious war between two people, an older agriculturally oriented Vanir religion, and a younger waroriented Æsir religion. In his thesis ${ }^{17}$ he argued that Gullveig was identical with Heiðr and the volva who speaks in Voluspá, and that they could be interpreted as a personification of the mythical mead as a mythical female being that belonged to the Vanir; as such, she was associated with the mythic mead and its mythical source. ${ }^{18}$

Sigurður Nordal believed that Gullveig was identical with Heiðr and that she was to be identified with one of the Vanir. 
Nordal essentially followed Müllenhof (above) when he assumed that she represented the power of gold and its intoxicating and seductive qualities. ${ }^{19}$

Yet another approach was to compare Gullveig's immolation with ritual activity. Anne Holtsmark ${ }^{20}$ thought that the torture of Gullveig might have something to do with some kind of "battle magic", where she represented an image of the enemy. Torment of that image meant that the same kind of injury would befall the one the imitation was meant to represent. The purpose was to give the Æsir an advantage in the approaching war with the Vanir. Another theory was proposed by Rudolf W. Fischer. ${ }^{2 \mathrm{I}} \mathrm{He}$ thought that the spears that strike and pierce (or are used to prop up) Gullveig three times, as well as her burnings, were a reflection of ancient ritual used in the purification of gold. Heino Gehrts ${ }^{22}$ also thought that the episode reflected ancient cultic practice; in his view it represented a ritual sacrifice and the battle that follows was consequently identified as a ritual combat. Initiation and warfare were also the perspectives preferred by Andreas Nordberg ${ }^{23}$ who argued that the ritual of spearing Gullveig was imitated in the cult and that the cosmological meaning was to spread the desire for gold and consequently to stimulate war in the world.

John McKinnell compared the burning of Gullveig with an episode from Grimnismál, where Óðinn is tortured between two fires with the purpose of obtaining knowledge from him. According to McKinnell, the gods try to do the same thing with Gullveig - they want to win gold, or learn how to create it themselves. The madness this results in is that the gods wage war against the Vanir. ${ }^{24}$ McKinnell has also suggested that Gullveig might be an idol or a gold foil figure ("guldgubbe") of Freyja, which is attacked by spears and burned: "Just as gold emerges refined from the fire, the cult of the goddess herself lives on; she is re-born, not as Heiðr, but as herself". ${ }^{25}$

Margaret Clunies Ross argued against the idea that Gullveig was an invention by the Voluspá poet(s), as the figure fits general themes in Old Norse mythology. ${ }^{26}$ Gullveig and Freyja are performing the same mythological functions, whether or not they were understood as being one and the same. She argues convincingly that there are some similarities between the arrival of the 
three giant maidens in stanza 8 and the advent of Gullveig. The reason is that the gods reject the possibility of a marriage alliance with these women and their own group. She explains that it might have been the Vanir who sent her in the hope of getting something in exchange, but that they become outraged when the Æsir attack and try to destroy Gullveig. ${ }^{27}$ This falls into her theoretical pattern of negative reciprocity, social relations between the Æsir, the Vanir, and the giants, in Old Norse mythology. ${ }^{28}$

Gullveig could also symbolically represent female powers. Gro Steinsland and Preben Meulengracht Sørensen thought that Gullveig and Heiðr were identical figures. They were not convinced that she should be interpreted only as Freyja. They suggested that she is rather a mythical feminine force that lives on in different forms: as Freyja, as the volva who speaks in Voluspá, and as Heiðr. Her killing is seen as a ritual killing. ${ }^{29}$ A different interpretation was presented by Else Mundal. In her opinion, a good way to approach Gullveig is to compare her with other mythical females that have been scorched by fire and associate them as personifications of "female chaos". Mundal thinks that Gullveig has been reborn in new shapes and that Angrboða could be one of them. Her argument partly rests on Hyndlulióð 4I, in which Loki devours a woman's burnt heart, upon which he becomes pregnant and gives birth to all the troll women (flagð) in the world..$^{\circ}$ Another woman who was scorched by fire is, of course, the giantess Hyrrokkin.

One of the most common identifications of Gullveig is that she is to be understood as a hypostasis of Freyja. This idea is usually traced back to Gabriel Turville-Petre. The theory has been favoured by many scholars. ${ }^{3 \mathrm{I}}$ In the words of Turville-Petre:

Gullveig can hardly be other than Freyja, the Vanadis and foremost of the Vanir [...]. It is not known how Freyja came to Ásgarð[r] or the hall of Óðinn, but if we can identify her with Gullveig, it was because of her that the war of the gods broke out. It could be suggested that Gullveig (Freyja) had been sent to Ásgarð[r] by the Vanir in order to corrupt the Æsir with greed, lust and witchcraft. Attempts by the Æsir to destroy her were vain, and she still lives. ${ }^{32}$

Ursula Dronke ${ }^{33}$ links Gullveig to the mysterious Porgerðr Holgabrúðr, who is also associated with gold. In an earlier article, 
she identified Gullveig with Freyja and proposed, with an imaginative reconstruction of the earlier stages of the myth, that Gullveig is an idol that is burnt to get back at the Vanir, whose forces were led by Freyja herself. ${ }^{34}$

The last theory to be presented here is not the latest, but has recently been picked up by Katja Schulz, ${ }^{35}$ and can, therefore, serve as a good bridge extending from earlier theories to my own. Eugen Mogk ${ }^{36}$ proposed that the war described in Voluspá is a Nordic version of a Gigantomachia, i.e. it concerns a war fought between the gods as a group and the giants. The gods march together against the giants but fare ill and are almost defeated; in the end they must offer Freyja, the sun and the moon to the giants. His idea is repeated by Katja Schulz in her thesis. ${ }^{37}$ Both of them consider Gullveig to be a giantess, and not one of the Vanir. ${ }^{38}$ This interpretation is worth considering, and I will return to this question below.

\section{Gullveig and Heiðr}

Before we turn the spotlight on Gullveig, a few words need to be said about an earlier stanza of the poem that introduces priar pursa meyiar, as I think they are of importance for solving the puzzle and can shed light on the elusive Gullveig-episode.

8 Teflðo í túni, teitir vóro, var peim vattergis vant ór gulli, unz priár quómu, pursa meyiar, ámátcar miqk, ór iotunheimom. ${ }^{39}$

They played chequers in the meadow, they were merry, they did not lack for gold at all, until three ogre-girls came, all-powerful women, out of Giant-land. $4^{\circ}$

Some critics have identified these three giantesses with the fates, but, in my opinion, there is no reason for doing so, as they actually appear in stanza 20. What is clear, however, is that the arrival of the three giant maidens somehow breaks the golden age that the gods up until now have prospered in. The tafl "board game" seems to indicate an aristocratic setting, which is confirmed by 
the abundance of gold, the very symbol of power and wealth. We know, then, that the poet(s) identified these three maidens with deterioration and the end of a peaceful and prosperous age. This narrative ends with the arrival of the giant women and moves on to speak of the creation of dwarves and list dwarf names (stanza 9-16), and then explains how human beings came into being (stanza I7-I8), and after that speaks of the appearance of the three fates (stanza 20). Reading this, it seems as if the narrative of the gods and their primordial age of prosperity is somehow broken off. When the narrative returns to the gods, it speaks of the torturing of Gullveig in the High One's Hall and the outbreak of the first war in the world.

Gullveig is, as mentioned previously, found nowhere else. The first element of her name, Gull-, is uncomplicated and means "gold", but the second element, -veig, is harder to interpret, because it can be associated with many different words and usages. It is usually, after Karl Müllenhof, ${ }^{4 \mathrm{I}}$ understood as "intoxication by gold", that is, as an allegorical figure that symbolizes the greed for gold. Lotte Motz ${ }^{42}$ interpreted the name as "golden (coloured) drink" and suggested that both Heiðr and Gullveig represented the first brewing of mead. John McKinnell ${ }^{43}$ has argued for another meaning, supported by a careful lexicographical study, where the second element should be understood as something that refers to "military power", or simply "woman". When linked to military power, the root is that found in ON vig "war" and Gothic weihan "to fight". ${ }^{44}$ The name is therefore interpreted as "woman made of gold", "gold-adorned woman", or "gold-adorned military power". ${ }^{45}$ In other words, McKinnell opens up for the possibility of interpreting her name in ways other than the common reading of its elements as "gold" and "drink".

In stanza 22, just after the immolation of Gullveig, the poem speaks of a female figure called Heiðr, skilled in seiðr, who came to houses. Who is she, and why is she specified as the favourite of a wicked woman? The name Heiðr can be found in several sagas as the name of a volva. ${ }^{46}$ The name in the sagas probably goes back to a mythical prototype. According to Jan de Vries, the name is just an epithet for a volva in general and not the personal name of a given person. Maybe the volur from the sagas have been 
given their name from a similar oral tradition to the poem? The name Heiðr can also be found in Hyndlulióð, stanza 32, listed with Hrosspjoffr as children of the giant Hrímnir. It is uncertain whether the poem lists two brothers, or a brother and sister (I prefer the latter reading). Nevertheless, the name is being used in this source as the name of someone who is of giant kin. The same poem, in stanza 33, also says that all volur derive from Viðólfr; a name that can be interpreted as "forest wolf" and therefore links the figure with uncultivated land and wilderness. The connection is interesting compared to the troll woman, probably a giantess, in Voluspá 39, who sit in Iron-wood (Iárnviði) and give birth to Fenrir's offspring (all the wolves in the world). Therefore, there might be some basis for considering Heiðr in Voluspá as a giantess who knew how to practice seiðr. Giants skilled in sorcery are a common motif in the Old Norse sources, especially in myths about Óðinn. In the poem, Heiðr is said to be a wicked woman's favourite.

Who is this wicked woman? There are a couple of female giants that are said to be wicked; one can be found in Hyndlulióð $4 \mathrm{I}$ and is the one from whom Loki eats a burned heart and becomes pregnant: "Lopt was impregnated by the wicked woman (af kono illri), from whom every ogress on earth is descended". The other giantess who is said to be wicked and mother of benign giants, is the volvalspeaker of Baldrs draumar. In stanza I3, Óðinn says, in a heated exchange of words, that she is not a seeress (volva), nor a wise woman (vís kona), but a mother of three giant women (priggia pursa móðir). Some of the giantesses that Pórr encounters on his journeys can also be considered wicked, for example the daughters of Geirrǫr (in Pórsdrápa and in Snorri's Skáldskaparmál I 8) or the giantesses he brags that he has killed in Hárbarðslióð (stanzas 23, 37-39).

The wicked woman who does harm to the gods, referred to in Voluspá, is probably a giantess; it might even be a reference to the volva herself or to Gullveig (or both). Else Mundal thinks that Heiðr is the joy of Gullveig, because she promotes disorder by way of her witchcraft and that they are both dangerous to the gods' world order. ${ }^{47}$ I think this is a reasonable explanation. Clunies Ross noted that in the whole of the Old Norse mythological 
corpus, Gullveig is the only non-giant female being who is killed by a male or by a group of males. ${ }^{48}$ The most common way to kill a sorcerer or witch was execution by destroying the individual by fire, something that is supported by continental Germanic and Scandinavian legal codes, as well as in the penal codes of the majority of the Indo-European peoples. ${ }^{49}$ Gullveig/Heiðr can be related to the three mighty giantesses mentioned earlier, that somehow managed to ruin the gods' prosperous age. If we consider that Gullveig/Heiðr is sent by the giants to the gods, and that she is a great practitioner of sorcery who wreaks havoc among the gods with her magic, and that the gods respond by trying to destroy her in flames, then the anomaly that Clunies Ross noted would simply disappear; she is indeed a female giant that a group of male gods try to kill. It would also be a reasonable cause for starting a war with the giant race.

When considering what we can glean of the principal elements of the mythical narrative about Gullveig so far, we can identify the following: the first war in the world was caused in some way by the actions of unnamed beings ("they stuck Gullveig with spears") in spearing and then burning her in the High One's (likely Óðinn's) Hall; they burned her three times, but she was reborn three times and she still lives. No information is given in stanza $2 \mathrm{I}$ as to who "they" were and who Gullveig was, but I think we can reasonably assume that "they" in this case were the gods (who are the inhabitants of Óðinn's Hall). The next stanza (22) then mentions that "they" called her Heiðr, wherever she came to houses. Who "they" are is not specified, but I will, following Clunies Ross, interpret them as "humans". ${ }^{\circ}$ Following the discussion above, this seems to indicate that Gullveig has transformed herself into a volva who practises seiðr. Consequently, this episode can be interpreted as a narrative that takes us from the mythic to the mundane. This contrastive sphere of activity, from a divine hall to a house, suggests that Gullveig/Heiðr has been translated from the divine to the human world. ${ }^{5 \mathrm{I}}$ This might also explain why the name is used for volur in the sagas; it might even suggest that it was meant to point to hostile elements known from mythological traditions, where it is used as a name for a perilous giantess, skilled in sorcery. 


\section{A Proto-typical War Fought Between Gods and Giants}

Immediately after the immolation of Gullveig and the appearance of Heiðr, the gods have a meeting and deliberate whether they ought to pay a tribute or share sacrificial feasts. Who they should pay tribute to is not mentioned, nor who should share the sacrificial feasts with them. It seems as if the gods decide not to pay tribute or share their feasts. Instead, it seems as if Óðinn's answer to this crisis is a declaration of war. In the next verse (stanza 24), Óðinn hurls his spear at (or over, as a sign of symbolic supremacy) the host of his enemies. ${ }^{52}$ But the war goes badly and the gods see their battlements broken down by their enemies. In this context, the Vanir and their proficiency with magic are mentioned. It does not say who they aim their spells at, but I think that they are marching out from the stronghold, entering the battlefield, wielding war-spells (vígspá). Their magic skills and the element of surprise are just what the gods need to turn the tide and strike back at their overwhelming enemies.

23 Pá gengo regin oll á rocstóla, ginnheilog goð, oc um pat gattuz,

hvárt scyldo cesir afrád gialda eða scyldo goðin oll gildi eiga. ${ }^{53}$

Then all the Powers went to the thrones of fate, the sacrosanct gods, and considered this: whether the Æsir should yield the tribute or whether all the gods should share sacrificial feasts. ${ }^{54}$

24 Fleygði Óðinn oc í fólc um scaut, pat var enn fólcvíg fyrst i heimi;

brotinn var bordveggr borgar ása, knátto vanir vígspá vollo sporna. ${ }^{55}$

Odin hurled a spear, sped it into the host; that was war still, the first in the world; the wooden rampart of the Æsir's stronghold was wrecked; the Vanir, with war-spell, kept on trampling the plain. ${ }^{56}$

Most commentators have interpreted the first war in the world as a war between the Æsir and the Vanir. ${ }^{57}$ This interpretation 
is dependent on Snorri Sturluson's narratives (Ynglinga saga 4 and Skáldskaparmál G. 57), where he makes it clear that the two tribes of gods fought. But his accounts do not resemble the one found in the poem. Snorri places it as a part of the creation of the mead of poetry; he never mentions Gullveig or Heiðr. It might be, as Clunies Ross $^{5}{ }^{8}$ has pointed out, that Snorri, for some reason, might have chosen to omit the passage of Gullveig, from his narrative as he also did with the sacrifice of Óðinn. ${ }^{59}$

If we look closer at stanza 24 , it could as easily mean that the giants had broken down the god's defences. The Vanir mentioned in the next line, knátto vanir vígspá vollo sporna, could be interpreted as a synonym for "gods", or simply indicate that the Vanir attacked the giants with their magic. Therefore, the poet(s) might have understood the two separate groups of gods as fighting a battle, not among themselves, but as allies against a common foe - the giants. The poet(s) use different synonyms for "gods" in the poem, and this instance is probably no exception. ${ }^{60}$

Lately, there has even been a discussion concerning the existence of the Vanir as a group. The idea was put forward by Rudolf Simek, ${ }^{61}$ who used philological arguments against the existence of the Vanir as a distinct group of gods. This heated debate is not really of interest here, although I would like to propose that there is nothing in the poem itself that supports a battle between Æsir and Vanir. ${ }^{62}$ Besides, if we turn to Snorri and his narrative of the Master Builder tale (Gylfaginning 42), it is quite clear that the giant who is the master builder is supposed to build a fortress that can protect the gods, not against the Vanir, but against the threat of giants:

Pat var snimma i gndverða bygð goðanna, pá er goðin hofðu sett Miðgarð ok gert Valholl, pá kom par smiðr nokkvorr ok bauð at gera peim borg á prim misserum svá góða at trú ok orugg vori fyrir bergrisum ok hrimpursum pótt peir komi inn um Miðgarð. ${ }^{63}$

It was right at the beginning of the gods' settlement, when the gods had established Midgard and built Val-hall, there came there a certain builder and offered to build them a fortification in three seasons so good that it would be reliable and secure against mountain-giants and frost-giants even though they should come in over Midgard. ${ }^{64}$ 
Another reason for considering the war as a war fought between gods and giants is that the following two stanzas (25-26) make it obvious that the giants are involved in a conflict with the gods. ${ }^{65}$ They have somehow stolen a goddess, and Pórr, the biggest enemy of the giants, becomes furious and seemingly breaks all kinds of oaths and sacred vows, presumably to get her back.

25 Pá gengo regin oll á rocstóla, ginnheilog goð, oc um pat goettuz, hverir hefði lopt alt loevi blandit eða aett įtuns Óðs mey gefna. ${ }^{66}$

Then all the Powers went to the thrones of fate, the sacrosanct gods, and considered this: which people had troubled the air with treachery, or given Od's girl to the giant race. ${ }^{67}$

26 Pórr einn par vá, prunginn móði, hann sialdan sitr, er hann slict um fregn; á genguz eiðar, orð oc sœeri, mál oll meginlig, er á meðal fóro. ${ }^{68}$

Thor alone struck a blow there, swollen with rage, he seldom sits still when he hears such a thing; the oaths broke apart, words and promises, all the solemn pledges which had passed between them. ${ }^{69}$

Pórr is inflamed by rage: all pledges, oaths and promises are broken apart (stanza 26). The reason is that Óðr's maid (Óðs mey) has been given to the giant race (stanza 25). This female figure can likely be understood as Freyja, who deceitfully has been given to the giants, something that must have resulted in a crisis for the gods (as a group). The person responsible for this trickery could very well be Loki; indeed, it would fit his trickster character and unreliable nature as we know him from the sources. ${ }^{70}$ It is up to Pórr to get her back, probably by the use of force and violence. This follows a mythological pattern where the giants try to steal the goddesses that we can easily recognize from other sources. ${ }^{71}$

There are, I believe, reasons for considering the primeval battle between gods and giants as an old mythic motif. A primordial war 
between gods and another race of beings is not unique for Old Norse mythology. It might be fruitful to consider comparative material from other mythological traditions, both Indo-European as well as other traditions. There are some parallels in oriental mythology, particularly among different succession myths and the conception of ancient gods vanquished to the underworld, for example in Greek, Hittite, Phoenician, and Babylonian mythology. ${ }^{72}$ The Babylonian god Marduk won his sovereignty by overthrowing Kingu, Tiamat, and their armies; while the Vedic god Indra won his by overcoming Vritra and Vritra's hosts. ${ }^{73}$ If we turn to Greek mythological traditions, there are descriptions of two great wars that the gods fought, first against the Titans and later against the Gigantes. As Walter Burkert says, "Power is latent violence which must have been manifested at least in some mythical once-upon-a-time. Superiority is guaranteed only be defeated inferiors". ${ }^{74}$

The giants (known as Titans and Gigantes) in Greek mythology are famous for waging wars against the Olympian gods - the Titanomachy and the Gigantomachy. There are various descriptions of these wars; the most detailed is the one between the gods and the Titans as an older generation and rival group for supremacy. The most comprehensive account is given in Hesiod's Theogony (e.g. line 6I $7-735$ ), a poem that is usually dated to the decades before or after 700 BC. A similar, but by no means identical, narrative can be found in Apollodorus' The Library..$^{75}$ A brief account of the main events can be summarized as follows: just as Kronos overthrew his father Ouranos, Kronos in turn is overthrown by his own son Zeus. It is this battle that is called the Titanomachy, where Zeus alongside his supporters and his brothers and sisters fought from Mount Olympos, while Kronos and many of the Titans fought from Mount Othrys. The war shook the universe to its foundations and the tumult is described as immense. It was as if heaven and earth collided. In the end, Zeus summoned the Cyclopes and the Hundred-handed. With their help they managed to overcome Kronos and his Titans. The Hundred-handed were set as prison guards over the Titans in the depth of Tartarus. The mother of the Titans, Gaia, became furious and urged her other children, the Gigantes, to go to war against 
the gods. Their overwhelming attack on Olympos could only be defeated with the help of a mortal, Herakles. After the Gigantes were beaten, another fearsome monstrous being called Typhon attacked the gods and challenged Zeus, who in the end managed to defeat the monster with his thunderbolts. ${ }^{76}$

The beings who challenge the gods' position as supreme, be it giants or something else, did not only represent primeval disorder, but all the terrible and frightening forces that still remain in the world and that could periodically threaten the order that the gods had secured by force: hurricane, flood, fire, volcanic eruption, earthquake, eclipse, disease, famine, war, crime, darkness, death, freezing cold, and so on. ${ }^{77}$ After the gods have fought with the giants in Voluspá, the world will slowly degenerate and ultimately be destroyed in a final battle. Most of the catastrophic and traumatic events listed above influence this period of disaster, among the gods as well as on earth. It will increasingly do so before the gods and the giants fight one last time and the earth is scorched by fire and sinks into the depths of the sea. Disastrous events of this kind are indeed described in Veluspá, especially from stanza 39 to 56.

Many of the suggested comparative sources can be used to argue that it might as well fit a war between two different tribes of gods, i.e. the Æsir and the Vanir, but most of the material found in comparative mythology seems to concern a generational schism between an older and a younger group of gods. There is nothing in the sources to suggest that the Æsir and the Vanir were related. But the giants on the other hand are, however, clearly described as an older generation of beings that are indeed related by blood to the Æsir (at least on their mother's side). ${ }^{78}$ Therefore, it is much more fruitful to associate the comparative mythological traditions with the gods and the giants, not between two separate groups of gods (albeit the giants in Old Norse religion were not considered to be an older generation of gods). In the mythological traditions, the primeval giants served as an explanation for how the world came into being and are regarded as mythological beings (without any cult).

The main point of these mythological traditions is to explain how the gods, with their use of force and cunning, defeated the 
giants. It also gives a reason for how they continue to fight and compete with them for power over the cosmos. This cosmological conflict and tension is a part of life for the sacred and the profane. In the end, this fight for dominance will end with Ragnarøk, a final powerful confrontation between the gods and the giants, which will affect all living things, and be the end of the world as we know it.

\section{Breaking the Sacred Rules of the Hall}

My arguments relating to the account given in Voluspá are linked to my general theory of interactions between gods and giants from the perspective of a hall. What really intrigues me is that the scene presented in the poem actually takes place in Óðinn's Hall, and that it is the gods who first resorts to violence, not the giants. From my point of view, sacrilegious acts in a hall and the breaking of the truce therein, might explain why the downfall of the gods starts with this episode and eventually leads to warfare and the breaking of words, promises, solemn pledges, and oaths.

When the gods try to shed blood and kill Gullveig, they break the grið "truce, pardon, peace" 79 of the hall, and this very act has severe consequences. The account of this violence in Óðinn's Hall seems to be important, even though it is hard to fully comprehend. I think that when the gods resort to violence against her, they also break the truce and sanctity of the hall (grið). The result might be that a new figure, by the name of Heiðr, appears. She might be Gullveig reborn, or another figure that represents wicked witchcraft. The episode is a part of the first war in the world. It was by pre-Christian moral standards considered shameful for men to injure women; physical aggression aimed at a woman was disgraceful. It was, furthermore, particularly insulting for the woman's male relatives. Therefore, it could be used as a weapon or strategy for serious defamation that demanded blood vengeance from the women's male relatives. The mythical episode mirrors a state of war. In this world, an extreme and hostile situation (war, violent conflicts, feuds, raids etc.) meant that women were killed or led away as slaves: rough treatment and assault against women, even rape, was not uncommon in this context. ${ }^{8 \circ}$ The volva 
who speaks in the poem is perhaps trying to insult Óðinn with this information; something that must have been truly shameful, as he actually failed to kill Gullveig.

Even though it is nowhere stated that the Æsir are Gullveig's aggressors, the mere fact that she is speared in Óðinn's Hall, is, I believe, strong indications that Óðinn is thought to be responsible for her immolation. Breaking the sacred rules of the hall leads to the downfall of the gods. In many myths, the hall serves as the centre for interaction between giants and gods. Like halls in this world, the mythic halls seem to be protected by the same sets of rules and prohibitions. When the gods are torturing and trying to kill a guest in their hall, the very rules that the gods are meant to uphold and care for are torn apart. Gullveig is not exactly described as a guest, but if we give it some thought, then the gods can be interpreted as representing hosts that act in a way that in every way is considered dishonourable. This kind of behaviour is, as is made clear in Hávamál, something that a host should avoid at all costs. The episode might also be an example of how grið became institutionalised. As Jarich G. Oosten reminds us of myths: "Many myths explain how the world arouse out of chaos, order out of disorder, and culture out of nature. This is often expressed in a paradoxical way in the structure of the myth itself: a cultural rule or norm is instituted because of the very act it prohibits" ${ }^{8 \mathrm{r}}$ This ill treatment of the unexpected guest can perhaps also, in the chronological order of the poem, be seen as progressing Ragnarøk. This is even more emphasized when Pórr breaks oaths, words, promises, and all the solemn pledges (stanza 25, after the first war). Again, it is the giants who are the enemy, and the battle that is fought in Voluspá is between gods and giants.

I believe that it is possible to assume that gold plays a major part in this episode and that it is also a major reason for the war. But it is hard to say whether the Gullveig-episode is the reason for the war or a result of it. I believe that Gullveig and Heiðr (even if we consider them as two different characters or one and the same) can be traced back to the advent of the giant maidens and the ending of a "golden age". The gods violate the rules of hospitality when they torment and try to kill her in their hall. This was not a minor offence, but a major breach of hospitality, that would lead to a war with the giants. 
Gullveig could symbolize a greed for gold, and gold had a major symbolic and powerful value and impact in Old Norse society, not least among chieftains and warriors. Power and wealth went hand in hand and are accompanied by war. We can perhaps understand Gullveig's role as someone who was sent by the giants to spread discord and desire among the gods - principles that could easily be understood by the audience of the poem. A crazed desire and craving for gold. It seems that it is the gods who are acting wrongly when they attack Gullveig in their hall, not the giants. This started the first great struggle for dominion in the world, not between different gods, but a war of gods against giants that will be continued until the breaking of the world.

In his study of Voluspá, Finnur Jónsson supports Müllenhof's notion that Gullveig's name has something to do with the powerful desire of gold and argues: "Det lå nu meget nær at antage at, at det var jætterne, der havde sendt Guldvég afsted; men det forholder sig dog ikke så." ${ }_{22}$ I disagree; the giants have probably, in my opinion, sent Gullveig to the gods, an action that makes the gods break sacred bonds in their hall, and leads to an ongoing conflict and fight for domination and power between gods and giants that characterizes Old Norse mythology as a whole. ${ }^{83}$

\section{Conclusion}

When I first wrote about Gullveig for my thesis, I was not aware that Mogk, Mundal and Schulz had already preceded me in thinking that she was a giantess, nor that Mogk and Schulz also thought that the war that followed was fought between gods and giants. I do, however, believe that this theory merits more attention. My main conclusion, as well as my own contribution to the study of Gullveig, is that the brutal treatment of her is a direct violation of grið; it is an act that breaks the sanctity and the truce that is supposed to be sustained in a hall. This, in turn, leads to a war with the giants. I believe that this is the first war in the world; therefore, I believe it was proto-typical. A war that is fought between gods and giants can also be found in Greek and Roman mythology and fits with a mythological pattern found in other mythological traditions. 
How does this reflect on a hall culture? The mythical tradition of a war between gods and giants in a primordial time can be seen as prototypical for warriors, warlords and chieftains. War and violence were glorified and praised, at least within a warrior ideology. Gullveig is a guest in Óðinn's Hall, and as such she is treated in violation of the rules and norms for a host-guest-relationship that the hall is supposed to secure and maintain. The gods violate grið and show how a cultural rule or norm is instituted because of the very act it prohibits. In a hall, rules and norms exist to maintain a status quo between a guest and a host. When someone, as a guest, entered and crossed the threshold of a hall, a suspense and uneasiness, both for the host and for the guest, manifested in the hall. The norm guaranteed safety and security within the hall building.

The narrative of Gullveig takes us from the divine to the human world, something we can gather from the description when, after she is immolated, it can be argued that Gullveig (a threat to the gods in the divine hall) is transformed and returns as Heiðr (a threat to humans in this world). The figure of Gullveig is, as we have seen, usually interpreted as Freyja. The torturing of her has consequently been seen as one of the crucial factors that lead to a warfare between two tribes of gods, the Æsir and the Vanir. I do not agree with this conclusion and have tried to consider another approach. In my opinion, Gullveig does not represent Freyja, nor anyone sent from the Vanir, and the war is not fought between two different tribes of gods. Instead, I believe this to be a version of the first clash between the gods and the giants as two conflicting groups, and I consider Gullveig to be a giantess, sent out by the giants to spread discord among the gods and make them break sacred vows. In the narrative, in the chronological order of events as presented in Voluspá, this is one of many factors that eventually lead to Ragnarøk.

\section{Notes}

I. See Kuusela 20I7. In this text I will use the term gods as a word that signifies divinities of both sexes (both gods and goddesses).

2. Only two different versions of Voluspá have survived, in the manuscripts Codex Regius and Hauksbók. Parts of the poem are quoted in Snorri Sturluson's The Prose Edda, but he does not mention Gullveig. 
The audience of the poem, however, ought to have known who she was, or at least have been able to figure it out without much effort. Gullveig is probably one of these figures that we only know of from one source, but who might have been well-known in oral tradition. Old Norse oral tradition must have been diverse, with numerous versions of myths and motifs than we no longer know of. In the following, the text quoted from The Poetic Edda is taken from the edition of Neckel and Kuhn (1962) and all of the translations are quoted from Carolyne Larrington (2014).

3. I base this statement on the fact that she refers to herself as being nurtured by giants, and that her first memory is of giants (stanza 2).

4. McKinnell $20{ }_{4}$ (200I):34.

5. Neckel/Kuhn I962.

6. Larrington 2014.

7. Neckel/Kuhn I962.

8. Larrington $20 \mathrm{I} 4$.

9. Müllenhof I 883 .

IO. This had actually been suggested earlier by Jacob Grimm (I 876-I 877:334).

I I. Bugge I867:38-39.

I2. Meyer I 889:92-II4.

I3. Krause I959.

I4. Krause I959.

I 5. Dumézil I973:24.

I6. Höckert I9I6.

I7. Höckert 1926.

I 8. E.g. Höckert I926:5 I-52, 85 . I will not repeat many of his, in my opinion, far-reaching ideas that echo Viktor Rydberg's ( I 886-I889) excessive attempts to bring together a diverse assembly of different female mythical beings from Germanic and Indian mythological traditions. Höckert repeated many of his ideas in I930, after severe 
criticism in a review of his thesis by Elias Wessén (I926) - a defence that was more extensive than his original thesis!

I9. Nordal I927:52-53.

20. Holtsmark I950.

2I. Fischer 1963.

22. Gehrts I969.

23. Nordberg 2003:94-99.

24. McKinnell I994: I I 8.

25. McKinnell 20I4 (200I):53.

26. The idea that Gullveig was a figment of a composer's imagination was proposed by Sigurður Nordal (I927:6I) and was later repeated by Jan de Vries (I962:194).

27. Clunies Ross I994:I98-2I I.

28. Clunies Ross I994:I03-I43.

29. Steinsland \& Meulengracht Sørensen I999:5 I-53.

30. Mundal 2002:I9I-I93. Even though the stanza does not actually say that the heart belongs to Angrboða.

3I. In the influential article on Gullveig in Reallexikon der Germanischen Altertumskunde Heinrich Beck (I999:190) trace the theory of Gullveig-Freyja back to Turville-Petre. Edgar C. Polomé ( $1995: 585$ ) mentions, in his article on Freyja, that she is identical to Gullveig and cause for the war between Vanir and Æsir. Cf. Näsström I995:63; Simek 2006:160.

32. Turville-Petre I964:I 59.

33. Dronke I 997.

34. Dronke I988:229.

35 . Schulz 2004.

36. Mogk I925.

37. Schulz 200I:I08-I09. 
38. As far as I know, Katja Schulz is the first person, since Eugen Mogk, to classify Gullveig as a giantess. The same identification was also proposed by Else Mundal (2002), but she does not make a reference to neither Schulz nor Mogk.

39. Neckel/Kuhn I962.

40. Larrington 2014.

4I. Müllenhof I 883 .

42. Motz 1993.

43. McKinnell 20I4 (200I).

44. Hugo Gering \& B. Sijmons (1927:27) also adds the Latin vīc-i to this group and argues for a connection with conquest and battle.

45. McKinnell 20I4 (200I):48.

46. The parallel between the names Gullveig and Heiðr is usually considered to be semantic; as ON heiðr 'fame', adj. 'shining' is in agreement with Gullveig, if the name is understood as "gold intoxication". The name Heiðr, however, can also be derived from the feminine noun heiðr, meaning "heath"; probably semantically related to the adj. heiðinn "heathen" (McKinnell 20I4 (200I):35).

47. Mundal 2002:193.

48. Clunies Ross 1994:208 n. I6.

49. Ström I942:I89-I98.

50. Clunies Ross I 994:204.

$5 \mathrm{I}$. I am indebted to Margaret Clunies Ross for proposing this interpretation (private correspondence).

52. Cf. Nordberg 2003:I07-I I 2.

53. Neckel/Kuhn I962.

54. Larrington $20 \mathrm{I} 4$.

55. Neckel/Kuhn I962.

56. Larrington $20 \mathrm{I} 4$.

57. Cf. Weinhold I890; Eckhardt I940; Dronke I988; Nordberg 2003:I07-I 20. 
58. Clunies Ross 1994:200.

59. The same could be said of the framework of Voluspá where Óðinn gains cosmological insights from the volva or in Vafprúðnismál where he gets it from Vafprúðnir in the giant's hall.

6o. Cf. stanza 4: Burs synir; stanza 6, 9, 23, 25: regin qll, ginnheilog goð; stanza 23: goðin oll.

6I. Simek 2010.

62. Cf. Simek 20IO; Frog \& Roper 20I I; Tolley 20I I; Schjødt 20 I 4.

63. Snorri Sturluson 2005:34.

64. Transl. Anthony Faulkes 2005:35.

65. In the Hauksbók-manuscript, this episode (2I-22) occurs earlier and is placed before the war (26); it is followed by a reference to Heimdallr's hearing (23), and then the giantess in the Iron-Wood giving birth to Fenrir's offspring that is said to threaten mankind and acts as a harbinger of Ragnarøk (24-25). Cf. Quinn 1990.

66. Neckel/Kuhn I962.

67. Larrington 2014.

68. Neckel/Kuhn I962.

69. Larrington 2014.

70. Cf. de Vries I933:253-254.

71. Cf. Clunies Ross 1994:I07-I27.

72. Burkert 2004:32-33.

73. Fontenrose I980:239.

74. Burkert I985:I28.

75. Apollodorus 1997:27-28, 34-35.

76. Cf. Nilsson I94I:480-486, Dowden 2006:35-39.

77. Fontenrose I980:2 19.

78. Óðinn and his brothers descended from Burr on their father's side, the son of the primordial ancestor Búri, and the giantess Bestla on their mother's side, who is the daughter of the giant Bollporn 
(Hávamál I40). Pórr is the son of Óðinn (in some sources) and a giantess (called Jǫrð, Hlóðyn or Fjǫrgyn). Heimdallr is descended from nine giant women (Hyndlulió 35-37). Týr is described as the son of a giant woman (Hymiskviða I I).

79. Fritzner I954:642-644.

80. Cf. Holtsmark I964, Jochens I99I, Brink 2012:85-9I, Charpentier Ljungqvist 2015.

8I. Oosten I98 5:6.

82. Finnur Jónsson I9 I I:23.

83. See Kuusela 2017 for more examples and arguments for the strained relationship between the gods and the giants and how they interact, many times with the aim of humiliating each other, especially in the context of a hall culture.

\section{References}

\section{Primary sources}

Apollodorus. Hard, Robin. 1997. The Library of Greek Mythology. Transl. Robin Hard. Oxford, New York: Oxford University Press.

Edda. Neckel, Gustav \& Hans Kuhn. I962. Die Lieder des Codex Regius nebst verwandten Denkmälern. I. Text. 3 rd Edition. Heidelberg: Carl Winter.

- Larrington, Carolyne. 20I4. The Poetic Edda. Transl. by Carolyne Larrington. $2^{\text {nd }}$ Edition. Oxford: Oxford University Press.

Snorri Sturluson, Edda. Faulkes, Anthony. 2005. Edda. Prologue and Gylfaginning. Edited by Anthony Faulkes. $2^{\text {nd }}$ Edition. London: Viking Society for Northern Research.

Secondary literature

Beck, Heinrich. I999. Gullveig. In H. Beck et al. (eds.). Reallexikon der Germanischen Altertumskunde, I3. 2nd Edition. Berlin \& New York: Walter de Gruyter, I90-I9I.

Bugge, Sophus. I 867. Norrœn fornkvœði: islandsk samling af folkelige oldtidsdigte om Nordens guder og heroer: almindelig 
kaldet Samundar Edda hins fróða. Christiania: P. T. Mallings forlagsboghandel.

Brink, Stefan. 20I2. Vikingarnas slavar. Den nordiska träldomen under yngre järnålder och äldsta medeltid. Stockholm: Atlantis.

Burkert, Walter. I985 (I977). Greek Religion. Transl. John Raffan. Cambridge: Harvard University Press.

Burkert, Walter. 2004. Babylon, Memphis, Persepolis. Eastern Contexts of Greek Culture. Cambridge, London: Harvard University Press.

Charpentier Ljungqvist, Fredrik. 20I 5 . Rape in the Icelandic Sagas. An Insight in the Perceptions about Sexual Assaults on Women in the Old Norse World. In Journal of Family History 40:4, $43 \mathrm{I}-447$.

Clunies Ross, Margaret. 1994. Prolonged Echoes. Old Norse Myths in Northern Society. Vol. I: The Myths. (Viking Collection, 7). Odense: Odense University Press.

Dowden, Ken. 2006. Zeus. (Gods and Heroes of the Ancient World) London and New York: Routledge.

Dronke, Ursula. I988. The War of the Æsir and the Vanir in Voluspá. In G. W. Weber (Ed.). Idee-Gestalt-Geschichte. Festschrift Klaus von See. Odense; Odense University Press, 223-238.

Dronke, Ursula. I997. The Poetic Edda. Vol. 2: Mythological Poems. Oxford: Clarendon.

Dumézil, Georges. I973 (1959). Gods of the Ancient Northmen. $2^{\text {nd }}$ Edition. Publications of the UCLA Center for the Study of Comparative Folklore and Mythology, 3. Berkeley \& Los Angeles: University of California Press.

Eckhardt. Karl A. I940. Der Wanenkrieg. Germanenstudien, 3. Bonn: Schriften des Deutschrechlichen Instituts.

Fischer, R. W. I963. Gullveig Wandlung: Versuch einer läutender Deutung des Kultes in Hars Halle. In Antaios 4, 58I-596.

Fontenrose, Joseph. I980 (I959). Python. A Study of Delphic Myth and Its Origins. Berkeley: University of California Press. 
Fritzner, Johan. I954 (I 886). Ordbog over det gamle norske sprog, I-III. Oslo: Møller.

Frog \& Jonathan Roper. 20II. Verses versus the 'Vanir': Response to Simek's 'Vanir Obituary'. In Retrospective Methods Network Newsletter 2, 29-37.

Gehrts, Heino. I969. Die Gullveig-Mythe der Voluspá. In Zeitschrift für deutsche Philologie 88, 3 I 2-378.

Gering, Hugo \& Sijmons, B. 1927. Die Lieder der Edda. Kommentar zu dem Lieder der Edda. Germanistische Handbibliotek. Halle: Buchhandlung der Waisenhauses.

Grimm, Jacob. I876-I877 (I835). Deutsche Mythologie, I-III. 4th Edition. Gütersloh: Bertelsmann.

Holtsmark, Anne. I950. Forelesninger over Voluspá, hösten I949 (Universities studentkontor). Oslo: Skrivmaskinstua.

Holtsmark, Anne. I964. Kvinnerov. In Kulturhistoriskt lexikon för nordisk medeltid IX. Malmö: Allhems förlag, 574-576.

Höckert, Robert. I9 I 6. Voluspá och vanakriget. In Festskrift tillägnad Vitalis Norström på 60-årsdagen den 29 januari I9I6. Göteborg: Wettergren \& Kerber, 293-309.

Höckert, Robert. I926. Voluspá och vanakulten. Uppsala: Almqvist \& Wiksell.

Höckert, Robert. I930. Voluspá och vanakulten, II. Uppsala: Almqvist \& Wiksell.

Jochens, Jenny. I99I. The Illicit Love Visit. An Archaeology of Old Norse Sexuality. In Journal of the History of Sexuality I:3, 357-392.

Jónsson, Finnur. I9I I. Völu-spá. Völvens spådom. Studier fra sprogog oldtidsforskning. Det philologisk-historiske samfund, 84 . København: Tillge's boghandel.

Jónsson, Finnur. I932. De gamle Eddadigte. København: Gads Forlag.

Krause, Wolfgang. I959. Gullveig und Pandora. In Skandinavistik 5, I-6. 
Kuusela, Tommy. 20I7. "Hallen var lyst $i$ helig frid": Interaktion mellan gudar och jättar, belyst frän perspektivet av en fornnordisk hallmiliö. Stockholm: Stockholms universitet.

McKinnell, John. 1994. Both One and Many. Essays on Change and Variety in Late Norse Heathenism. Philologia: saggi, ricerche, edizioni, I. Roma: Il Calamo.

McKinnell, John. 20I4 (200I). On Heiðr and Gullveig. In D. Kick \& J. D. Shafer (eds.). Essays on Eddic Poetry. Toronto Old Norse and Icelandic Series, 7. Toronto: University of Toronto Press, 34-58.

Meyer, Elard H. ı 889. Völuspa. Eine Untersuchung. Berlin: Mayer \& Müller.

Mogk, Eugen. I925. Zur Gigantomachie der Voluspá. In Folklore Fellowship Communications 58, Helsinki: Suomalainen tiedeakatemia, I-IO.

Motz, Lotte. I993. Gullveig's Ordeal. A new interpretation. In Arkiv för nordisk filologi 108, 80-92.

Müllenhoff, Karl. I883. Ueber die Völuspá. In Deutsche Altertumskunde 5:I. Berlin: Weidmann, I-I 57.

Mundal, Else. 2002. Austr sat in aldna ... Giantesses and Female Powers in Voqluspá. In R. Simek \& W. Heizman (eds.). Mythological Women. Studies in Memory of Lotte Motz (1922-1997). Studia Medievalia Septentrionalia, 7. Wien: Fassbaender, I 8 5-I95.

Nilsson, Martin P. I94I. Geschichte der Griechischen Religion, I. München: C. H. Beck.

Nordberg, Andreas. 2003. Krigarna i Odins sal: dödsföreställningar och krigarkult i fornnordisk religion. Stockholm: Stockholms universitet.

Näsström, Britt-Mari. I995. Freyja. The Great Goddess of the North. Lund Studies in History of Religions, 5. Lund: University of Lund.

Oosten, Jaarich G. I985. The War of the Gods. The Social Code in Indo-European Mythology. London: Routledge.

Polomé, Edgar, C. I995. Freyja. In Reallexikon der germanische Altertumskunde. 2nd Edition. Band 9. Berlin, New York: de Gruyter, 584-587. 
Quinn, Judith. I990. Voluspá and the Composition of Eddic Verse. In T. Pàroli (ed.). Poetry in the Scandinavian Middle Ages. Proceedings of the Seventh International Saga Conference. Spotelo: Presso la Sede del Centro Studi, 303-320.

Rydberg, Viktor. I 886-I 889. Undersökningar i germanisk mythologi, I-II. Stockholm: Albert Bonnier.

Schjødt, Jens-Peter. 20I4. New Perspectives on the Vanir Gods in Pre-Christian Scandinavian Mythology and Religion. In T. R. Tangherlini (ed.). Nordic Mythologies. Interpretations, Intersections and Institutions. Berkley, Los Angeles: North Pinehurst Press, I9-34.

Schulz,Katja. 2004.Riesen. Von Wissenshüternund Wildnisbewohnern in Edda und Saga. Skandinavistische Arbeiten, 20. Heidelberg: Winter.

Simek, Rudolf. [1984] 2006. Lexikon der germanischen Mythologie. $3^{\text {rd }}$ revised edition. Stuttgart: Alfred Kröner.

Simek, Rudolf. 20I0. The Vanir. An Obituary. In Retrospective Methods Network Newsletter I, IO-I9.

Steinsland, Gro \& Preben Meulengracht Sørensen. I999. Voluspå. Oslo: Pax forlag.

Stubbs, H. W. I959. Troy, Asgard, and Armageddon. In Folklore 70, 440-459.

Schjødt, Jens Peter. 20I4. New Perspectives on the Vanir Gods in pre-Christian Scandinavia Mythology and Religion. In $\mathrm{T}$. R. Tangherlini (ed.). Nordic Mythologies. Interpretations, Intersections, and Institutions. Berkeley \& Los Angeles: North Pinehurst Press, I9-34.

Sigurður Nordal. I927 (I923). Völuspá. Vølens spådom. Transl. Hans Albrectsen. København: Aschehoug, dansk forlag.

Ström, Folke. I942. On the Sacral Origins of the Germanic Death Penalties. Lund: Håkan Ohlssons boktryckeri.

Tolley, Clive. 20I I. In Defence of the Vanir. In The Retrospective Network Newsletter 2, 20-28. 
Turville-Petre, Gabriel. 1964. Myth and Religion of the North. The Religion of Ancient Scandinavia. New York: Holt, Rinehart and Winston.

de Vries, Jan. 1933. The Problem of Loki. Folklore Fellowship Communications, I ıо. Helsinki: Suomalainen Tiedeakatemia.

de Vries, Jan. 1962. Altnordisches etymologisches Wörterbuch. $2^{\text {nd }}$ Edition. Leiden: Brill.

Weinhold, Karl. I 890. Über den Mythus vom Wanenkrieg. In Sitzungsberichte der Könglich Preußischen Akademie der Wissenschaft zu Berlin I 890, II, 6 I I-625.

Wessén, Elias. I926. Anmälan. Vọluspá och vanakulten, I. Akad. Afhandl. af Robert Höckert. In Arkiv för nordisk filologi 43, $72-87$. 


\section{Response}

Eldar Heide

University of Bergen

Kuusela draws attention to quite a number of points in the sources which fit best with understanding Gullveig in Voluspá 2I as a giantess, rather than Freyja or some unspecified female being, and the war in Voluspá 24 as a war between the giants and the gods, rather than between the two groups of gods. It is a good point that stanza 25 refers to a conflict involving the giants, and that Snorri, too, says that the wall around Ásgarðr, which is generally understood as being identical with the borðveggr ása in Voluspá 24 , is supposed to protect the gods from the giants. I agree that the mention of the Vanir and their war magic in stanza 24 does not require that the Vanir are the Æsir's opponents in the battle; the idea may well be that war magic is the Vanir's responsibility in their alliance with the Æsir. It also seems very significant that the Æsir's killing of Gullveig would be an anomaly if she were not a giantess, because the Æsir sometimes kill giantesses but not other female beings. In addition, it fits well with this understanding that Heiðr is the name of a giantess in several sources, because most scholars believe that Heiðr in stanza 2I and Gullveig in stanza 22 are one and the same. Finally, it makes sense to see the cruelty inflicted upon Gullveig in Óðinn's Hall in relation to the hostility between the gods and giants that accelerates through the mythological history and ends with victory for the giants in the apocalyptic Ragnarøk battle. It is not correct, however, that "the downfall of the gods starts with this episode". As Kuusela himself notes earlier in the article, the downfall of the gods in Voluspá starts with the arrival of the enigmatic giantesses in stanza 8 .

As Kuusela points out, it is a problem in the interpretation of Mogk, Schulz, Mundal and himself that Snorri presents the war in question as one between Æsir and Vanir. ${ }^{\mathrm{I}}$ Rejecting Snorri's version is not in itself too problematic, if there are strong reasons for doing so, because there are several cases (when we know Snorri's sources) where his presentation is disputed by today's scholars (e.g. 
the idea that the Norse gods live in heaven ${ }^{2}$ ). It is hard, though, to see a plausible reason why Snorri would, in a myth about a war between gods and giants, replace the giants with the Vanir. (In the case of the gods living in heaven, Christian influence is an obvious explanation.) After all, the antagonism between gods and giants is essential to his presentation of Old Norse mythology, so we should expect that a primordial war between these two groups would suit him well. Also, Snorri's version to some degree is supported by other Eddic poems. According to Vafprúðnismál 38-39 and Lokasenna 34-35, Njorðr was sent from the Vanir to the Æsir as a hostage. This would normally imply a settlement of a conflict between Vanir and Æsir, ${ }^{3}$ and it happened, apparently, at a very early point in mythological history. The Vanir's magic in the world's first war in Voluspá 24 fits well into this. For this reason, I find it problematic to reject Snorri's account.

Kuusela says that interpreting Gullveig in Voluspá $2 \mathrm{I}$ as a giantess implies "a new analysis of the first war in the world according to how it is described in Old Norse mythic traditions". We might, however, have to distinguish between the first war in the world and the information about it found in Voluspá 2I-26. If we look at Voluspá in isolation, the more plausible interpretation may be that the first war was one between the gods and the giants. But, there is evidence of such a war between the Vanir and the Æsir, too. This could mean that there were two myths about this, or two versions of it, similar to how there were two myths of how the world was created (raised from the sea, in Voluspá 4, or made from the giant Ýmir's body, in Vafprúðnismál 20-2I). It is also conceivable that the Vanir and the giants were allies in the same war against the Æsir. Perhaps this could shed light on the enigmatic link between the hostage exchange of Njorðr and his humiliation by the giant Hymir's maidens in Lokasenna 34 - because, in retrospect, such an alliance would probably be seen as deeply humiliating. This would also be a good reason for Snorri not to mention the alliance. Could it also make sense of Hymiskviða's information that Týr was the son of Hymir? We have no information about how Týr came to the gods, but could he, too, have come there as a hostage? He functions as a hostage guaranteeing a deal with one of the powers of chaos in the only preserved myth 
about him, the one about the binding of the Fenrir wolf. ${ }^{4}$ And in this myth, the gods break their own promises, similar to how they act in Kuusela's interpretation of Voluspá 2I and in Voluspá 26. About these questions, we can only speculate.

This is an interesting and well-argued article about an essential, but, alas, probably unsolvable, question in Old Norse mythology. It is no accident that around Io previous interpretations of the Voluspá stanzas in question are mentioned in Kuusela's research overview.

\section{Notes}

I. Ynglinga saga I94I ch. 4:I2-I3; Skáldskaparmál 4, Edda Snorra Sturlusonar I93 I:82

2. Edda Snorra Sturlusonar 193I:25, 19-20, 22, 25, 29-3I, 33 (Gylfaginning 9, 6, 8, 9, I0, I I, I3, I 8). Cf. Schjødt I990:40ff., Heide 20I4, especially p. I Iо.

3. Olsson 2016.

4. Gylfaginning 2 I, Edda Snorra Sturlusonar I93 I:37.

\section{References}

\section{Primary Sources}

Snorri Sturluson, Edda. Finnur Jónsson. I93I. Edda Snorra Sturlusonar. Ed. Finnur Jónsson. København: Gyldendal.

Ynglinga saga. Bjarni Aðalbjarnarson. I94I. Heimskringla I. Ed. Bjarni Aðalbjarnarson. Íslenzk fornrit XXVI. Reykjavík: Hið íslenzka fornritafélag, I-83.

\section{Secondary Literature}

Heide, Eldar. 20I4. Contradictory Cosmology in Old Norse Myth and Religion - But Still a System?. In Maal og Minne, I02-43.

Olsson, Stefan. 2016. Gísl. Givande och tagande av gisslan som rituell handling $i$ fredsprocesser under vikingatid och tidig medeltid. Ph.D. thesis. Bergen: University of Bergen. 
Schjødt, Jens Peter. I990. Horizontale und vertikale Achsen in der vorchristlichen skandinavischen Kosmologie. In T. Ahlbäck (ed.). Old Norse and Finnish Religions and Cultic Place-Names. Based on Papers Read at the Symposium on Encounters between Religions in Old Nordic Times and on Cultic Place-Names Held at Åbo, Finland, on the $19^{\text {th }}-2 I^{\text {st }}$ of August 1987. Scripta instituti Donneriani Aboensis I3. Åbo: Instituti Donneriani Aboensis, $35-57$. 
